\title{
THE PATH NOT TAKEN: THE ANARCHIST ALTERNATIVE IN CHINESE SOCIALISM, 1921-1927*
}

SUMMARY: Until the late 1920s, anarchism was still a significant presence in Chinese radical thinking and activity, and till the middle of the decade, gave serious competition to the Communists. The essay discusses the nature of the anarchist movement in China, anarchist criticism of Bolshevik Marxism, and anarchist revolutionary strategy and activity during 1921-1927. It argues that while anarchists were quite innovative with regard to revolutionary strategy, their repudiation of organized power deprived them of the ability to coordinate revolutionary activity on a national scale, and what success they achieved remained local and short-lived. Indeed, the Communists were able to make better use of anarchist tactics than were the anarchists themselves. Anarchist critique of power rested on a denial of a center to society (and history). While this undercut the anarchists' ability to organize the revolutionary movement, it is also revealing of a basic problem of socialist revolution: the problem of democracy. In ignoring the anarchist critique of power, the successful revolutionaries deprived themselves of a critical perspective on the problem of socialist revolution, and were left at the mercy of the new structures of power that they brought into existence. Hence the importance of recalling anarchism.

The appearance and rapid ascendancy of Marxian Communism (or Bolshevism) in the 1920s has long overshadowed in historians' consciousness the other social revolutionary ideology on the Chinese scene: anarchism, which not only had nourished social revolutionary thinking and activity for the previous decade and a half, and contributed directly to the founding of the Communist Party of China in 1921, but well past the establishment of Communism, continued to serve as a fecund source of social revolutionary ideals that kept alive a radical alternative to Bolshevism. ${ }^{1}$

My goal in the following pages is to recall anarchism to the light of memory, delineating in outline anarchist thinking and activity during this period, which not only overlapped with the Communist conception of revolution but also sharply differed with it on questions of strategy and the

* An ad hoc research grant from the Hoover Institution and a travel grant from the Stanford University East Asia Center in the Summer of 1984, and a research grant from the Duke University Research Council in 1988 were of enormous help in conducting the research that has made this article possible. I gratefully acknowledge the help of these institutions, as well as of Ramon Myers, curator of the Stanford East Asia Library.

"Since anarchists and Marxists both claimed "communism" for their own, I distinguish the two below by capitalizing Marxist/Bolshevik Communism. 
ultimate premises of revolution. Communist Party spokesmen (then and now) have charged that anarchism was a petit-bourgeois ideology that offered no viable strategy of revolution. By the late twenties, when the decline of anarchism as a contender in the revolution had become all too apparent, anarchists themselves were willing to concede some validity to this assessment, at least to the latter part of it. I would like to suggest here that while the anarchist approach to revolution was indeed ineffective, this was due in some measure to a conscious self-limitation on the part of anarchists over the choice of revolutionary strategy, which in turn was a consequence of their efforts to remain true to the revolutionary ideals imbedded in the anarchist vision. In terms of specific revolutionary tactics, and at the local level, anarchists were quite creative. They took the lead in China in devising tactics of popular mobilization which, without consequence in their hands, would be put to effective use by the Communist Party in its own quest for revolution. The contrast has much to tell us about the ingredients that made for revolutionary success in the circumstances of Chinese society, but also about the price that revolutionary success was to exact in the attenuation of revolutionary ideals.

Anarchists demand our attention not for who they were or what they accomplished but because against a revolutionary strategy that presupposed a necessary compromise of revolutionary goals in order to confront the demands of immediate political necessity, they reaffirmed a revolutionary consciousness (or should we say, conscience?) that provides an indispensable critical perspective from the left on the unfolding of the Chinese revolution. As with anarchism worldwide (with one or two exceptions), anarchism in China went into a decline during the decade following the October Revolution in Russia, and would disappear as a significant force in radical politics by the late twenties. The decline of anarchism was in historical hindsight not just the decline of anarchist influence, but signalled the disappearance of a social revolutionary vision that had fashioned radical thinking for the previous two decades.

The significance of anarchism does not lie merely in the critical perspective it affords to historians and socialists. In the eyes of contemporaries, anarchism was a serious contender in the Chinese revolution and, at least until the mid-twenties, there were more anarchists than Marxian communists in China. So long as Chinese radicalism retained the exuberant idealism that had characterized it around the turn of the decade, anarchism continued to impress radicals for the authenticity of its revolutionary vision. In the midst of the mass mobilization of the $1920 \mathrm{~s}$, the revolutionary movement in China appeared not as the work of revolutionaries (as it had earlier and would again after 1927) but as the outburst of a spontaneous popular revolutionary fervor that sought not only to break with the past but also promised seemingly limitless possibilities for the future. In this envi- 
ronment, anarchism exerted considerable appeal, and revolutionaries continued to imagine as a real possibility a China reorganized along the lines of anarchist social models. Even after anarchists ceased to exert influence on the revolutionary movement, moreover, ideas and strategies of revolution that were of anarchist inspiration lived on in the thinking of important figures of the two major political contenders on the Chinese scene, the Nationalist Party (Guomindang) and the Communists. The Guomindang flirtation with anarchist ideas in 1927-1928 came to a quick end as the Party abandoned its previous social revolutionary orientation. The Communists were able to make better use of them in the new revolutionary strategy they devised after 1927, if with purposes contrary to anarchist goals, and with results that contravened anarchist intentions.

\section{The anarchist presence in the revolutionary movement}

Is it possible to speak of an anarchist movement in China? I think so, so long as "movement" is not restricted to activities whose motions are determined from an identifiable center - an assumption that was the object of the anarchist challenge to the other social revolutionary movements of the time. In the ideological topography of Chinese radicalism in the $1920 \mathrm{~s}$, anarchism was a pervasive presence without a center, concentrated around nodes of ideological dissemination and social activity which shifted with changes in the fortunes of the revolutionary movement.

The ideological diffuseness and organizational "decenteredness' of anarchism (the two were different sides of the same coin) make it difficult to identify anarchists, or to define the contours of anarchism as a movement. The appeals of anarchism in China were variegated. While all anarchists shared a common social idealism (many at this time traced their conversion to reading Kropotkin's "An Appeal to Youth") that expressed itself in the repudiation of authority, especially of the state and the family, what they found in anarchism is another matter. For different anarchists, anarchism expressed everything from trivial acts of anti-authoritarianism to rebellion against the suffocating authority of the family, of the oppression of women by men and of youth by their elders, to an esthetic promise of individual liberation, all the way to the pursuit of a social and economic equality that was barely distinguishable from that of the Communists. Even among the "social anarchists", who will be our main concern here, anarchism provided a refuge for modernists who identified it with the truth of modern science and uncompromisingly rejected a prescientific past, as well as for antimodernists who, in their frustration with modern society, sought back in the past the promise of a good society. In the early twenties, anarchist ideals were diffused broadly in radical thinking; even those who in 1921 would establish the Communist Party of China before then shared the outlook of anarchism, if they did not actually identify themselves as anarchists, and 
would retain anarchist affinities after their conversion to Bolshevism. Some of the most distinguished anarchists were also members of the Guomindang, though in theory they rejected politics, and would play an important part in the Guomindang suppression of Communists (and of anarchists) in the late twenties. Anarchist commitments had such an evanescent quality that even anarchists were on occasion unsure of the seriousness of commitment not just of rank-and-file fly-by-night anarchists but of those who played leadership roles in the movement.

Anarchist attitudes toward organization compounded (we might even say were responsible for) the problem. Strict organizational affiliation, which quickly disciplined a comparable ideological diffuseness among Marxists in the early 1920 s, is of no help in delineating the anarchist movement because anarchists repudiated the subjection of the individual to the organization, and of the peripheries of the movement to a center; jealous of local autonomy (localized ultimately at the individual level), anarchists were at one in rejecting centralized regulation of their thinking and activities. Anarchist organizational rules, rather than requiring members to subscribe to a well-defined set of rules, often stipulated only that they "do not oppose" the revolutionary goals of anarchism, which themselves were often very vaguely stated. ${ }^{2}$ According to one writer, there were in the early twenties "several thousand" anarchists in China (which figure, at best an estimate, probably included fly-by-night anarchists). ${ }^{3}$ These anarchists had their own local organization and pursued their own localized activities which not only differed from one another but were, in some cases, antithetical. Between 1919 and 1925, ninety-two anarchist organizations came into existence in China (some only short-lived). ${ }^{4}$ Evidence of the widespread popularity of anarchism, the proliferation of anarchist organizations is indicative also of the absence of a center to anarchist activity. In the absence of organized direction, we might add, individual loyalty and seriousness had to assume the burden for ideological integrity and consistency of purpose. Anarchism was not just individualized, it also called for great demands upon the individual which in the end only a few were able to meet.

It does not follow, however, that there was no logic or pattern to anar-

2 "Shishedi yiqu he dagang" (the Goals and Program of Truth Society), Banyue (Half Moon), 14 (15 February 1921), in Ge Mouchun et al. (eds), Wuzhengfu zhuyi sixiang ziliao xuan (Selections of Anarchist Thought) 2 vols (Beijing, 1984), II, pp. 527-530, p. 529.

${ }^{3}$ Xiao xing, "Zemmayang xuanchuan annaqi zhuyi" (How Should We Propagate Anarchism), Huzhu yuekan (Mutual Aid Monthly), 1 (15 March 1923), in Ge et al., Wuzhengfu zhuyi sixiang, II, pp. 682-685, p. 683.

${ }^{4}$ See the list in Ge et al., Wuzhengfu zhuyi sixiang, II, pp. 1061-1066. 
chist activity. Though the movement lacked a center, it is possible to identify in the midst of confusion a number of "nodes" of ideological and social activity that were more "central" than the others (this was especially the case for the social anarchists under discussion here). These nodes, and the individuals active in them, provided the anarchist movement with continuity over the years, as well as some measure of ideological coherence and an identifiable pattern of activity. They were crucial in the dissemination of anarchist ideology. And they served both in organization and activity as models for anarchists all over China. Certain individuals appear with regularity in anarchist publication and social activity, and were given recognition in the movement as its leaders, not by organizational regulation but by the acclaim of their fellow anarchists.

\section{Anarchism before the May Fourth Movement}

The centers of Chinese anarchism in its origins lay outside of the physical boundaries of China, in overseas Chinese communities in Paris and Tokyo. One center was the Society for the Study of Socialism (Shehui zhuyi jiangxi hui) that was established in Tokyo in 1907 by the classical scholar Liu Shipei and his wife He Zhen. The anti-modernist, agrarian oriented anarchism that the Tokyo anarchists promoted in the two journals they published would have a lasting effect on the thinking of some Chinese anarchists, but this society was in existence for only a brief period, and its impact on the anarchist movement per se was limited, with possibly one exception.

More important in this regard was the World Society (Shijie she) that was established in Paris in 1906, and would serve for decades as a conduit between European and Chinese anarchism. Its founders and leaders, $\mathrm{Li}$ Shizeng and $\mathrm{Wu}$ Zhihui, were among the doyens of Chinese anarchism. They were also close associates of Sun Zhongshan (Sun Yat-sen) and important members themselves of the Guomindang, in which capacity they would play important roles in the 1920s in anarchist anti-Communism, as well as in the problematic relationship the anarchists would enter with the Guomindang after 1927. The modernist, even scientistic, anarchism they promoted (inspired by Kropotkin) would fashion the thinking over the years of most Chinese anarchists. The "diligent-work frugal-study" program they initiated after 1912 to educate Chinese students in Europe was to serve as a recruiting ground for anarchists (though, ironically, it would also count among its graduates some of China's most prominent Communists, including Zhou Enlai and Deng Xiaoping). This program, which not only sought to bring to Chinese intellectuals a consciousness of labor but also brought them together with Chinese laborers abroad (who were brought to Europe during World War I to work in European armies and factories, also through the intermediacy of $\mathrm{Li}$ and $\mathrm{Wu}$ !) was to have a far-reaching impact on the Chinese revolution. 
If anarchism in China appears at first sight as primarily a southern Chinese, specifically Guangzhou (Canton) phenomenon, this impression which is at least partially valid is a product of the important role Guangzhou anarchists were to play for two decades, not just in the south but all over China, as well as in Chinese communities in Southeast Asia and as far away as San Francisco and Vancouver. The founding father of Guangzhou anarchism was Liu Sifu, better known under his adopted name Shifu, who at his death in 1915 was to leave behind an image as the paradigmatic anarchist, as well as a devoted following determined to complete the task he had initiated. While there may have been anarchists in Guangzhou before 1911, the origins of Guangzhou anarchism go back to the Conscience Society (Xinshe) that Shifu had established soon after his conversion to anarchism. In 1914, he and his followers moved to Shanghai to escape government persecution where he established, shortly before his death, the Society of Anarcho-Communist Comrades (Wuzhengfu gongchan zhuyi tongzhi hui). This society served as a model for similar societies established shortly thereafter in Guangzhou (led bu Shifu's brother, Liu Shixin) and Nanjing; Liu Shixin's group included Ou Shengbai, Liang Bingxian, Huang Lingshuang and Huang Zunsheng all of whom were to achieve prominence as leaders in the anarchist movement in the May Fourth period. ${ }^{5}$ The Federation's journal, People's Voice (Minsheng), published until 1922 (irregularly after Shifu's death) was to provide much needed continuity in the anarchist movement. Members or associates of Shifu's group were also responsible for initiating a syndicalist movement in China; in 1917 they were able to organize barbers and tea-house clerks in Guangzhou into China's first modern labor unions, and in 1918 they led the way in China's first May Day celebration in Guangzhou. According to one account, an associate of Shifu's group, Liang Bingxian, was the editor of the first labor journal to be published in China, Labor (Laodong), published in Shanghai in $1918 .{ }^{6}$ By 1921, anarchists had organized "at least forty unions" in Guangzhou. ${ }^{7}$

${ }^{5}$ Liu Shixin, "Guanyu wuzhengfu zhuyi huodongdi diandi huiyi” (Remembering Bits and Pieces of Anarchist Activity), in Ge et al., Wuzhengfu zhuyi sixiang, II, pp. 926-939, p. 937.

${ }^{6}$ Ibid., p. 934. In an earlier work, I referred to Wu Zhihui as editor of this journal. Zheng Peigang, who was also involved with the journal, confirms Liu's recollection that Liang was the editor. See Zheng Peigang, "Wuzhengfu zhuyi zai Zhongguodi ruogan shishi" (Some Facts on Anarchism in China), in Guangzhou wenshi ziliao (Historical and Literary Materials on Guangzhou), 1 (April 1962), pp. 171-208, p. 185.

${ }^{7}$ Huang Yibo, "Wuzhengfu zhuyizhe zai Guangzhou gao gonghui huodong huiyi" (Recollections of Anarchist Labor Activities in Guangzhou), in Guangzhou wenshi ziliao, 1 (April 1962), pp. 1-15, p. 3. 
After Shifu's death, there was no single figure to match him in stature in the anarchist movement. But Guangzhou anarchists continued to play leadership roles in the movement both in Guangzhou, and in other parts of China to which the student ferment of the late 1910s took them. In Guangzhou, Shifu's brother Liu Shixin and other members of the group such as Huang Zunsheng emerged as labor leaders. Anarchists from Guangzhou, most prominent among them Huang Lingshuang, Ou Shengbai, Zheng Peigang, Yuan Zhenying and Hua Lin, were to found the first anarchist group in Beijing, where they had congregated in 1917 as students and teachers at Beijing University. The society they established, Truth Society (Shishe), played an important part in infusing anarchist ideas into the New Culture Movement led by Beijing University professors and students. In early 1919, Truth Society merged with other anarchist societies in Guangzhou and Nanjing to establish an umbrella organization, Evolution Society (Jinhua she). The society's journal of the same name was edited by Chen Qiaonian who wrote under a pseudonym articles critical of his famous father, Chen Duxiu, leader of the New Culture Movement and later the first secretary general of the Communist Party, who had little patience for anarchists. In early 1920, we also encounter Guangzhou anarchists in Zhangzhou in Fujian province, which thereafter served as a center for the dissemination of anarchism. Liang Bingxian was the editor of Fujian Star (Minxing) the anarchists published in Fujian.

\section{Anarchists and Communists in the May Fourth period}

The year following the May Fourth Movement of 1919 was a turning point in Chinese radicalism, as well as the fortunes of anarchism. Though the movement was a product of patriotic resentment against the Versailles Treaty, the mass mobilization that accompanied it, especially the political emergence of Chinese labor, made socialism into an immediate issue of Chinese politics. In an immediate sense, anarchists were beneficiaries of this turn in Chinese radicalism. Anarchism was the most popular and pervasive of all socialisms in China in 1919, as was evidenced not only by the rapid proliferation of anarchist societies all over China, but also by the diffusion of anarchist ideas in the thinking even of those who were not anarchists. It was also at this time, however, that Chinese intellectuals began for the first time to show a genuine interest in Marxism as an ideology of revolution. Comintern initiatives to promote Communism in China, starting in 1919, also turned radicals to consideration of the possibilities of establishing a political organization to guide the growing mass movement. These developments would present the anarchists, with their opposition to politics, with an unprecedented challenge from the left.

In order to appreciate the significance for anarchists of these new developments, it is necessary to remember that there were no committed Marx- 
ists or Marxian communists in China in 1919. A Communist political identity would not assume recognizable form among Chinese radicals until after the establishment of a Communist political organization in late 1920 . As of 1919, Chinese radicals, including the later founders of the Communist Party (with the sole exception of Chen Duxiu), displayed a diffuse radicalism in which anarchist ideas were most prominent; communism was still understood by most as anarcho-communism. Also, anarchists were still the most readily identifiable group on the social revolutionary left, which may account for the anxiousness of the Comintern to include anarchists in the political organizations it sought to establish in China.

According to the anarchist Zheng Peigang, initial Comintern overtures bore fruit in late Summer 1919 in the establishment of "socialist alliances" (shehui zhuyizhe tongmeng) in major cities. ${ }^{8}$ In Beijing, Huang Lingshuang cooperated with his colleagues at Beida (and later leaders of the Communist Party) Chen Duxiu and Li Dazhao to establish the first of these alliances. Radicals in other parts of China followed suit. These alliances were to serve as the basis in 1920 for the Marxist Study Societies that sprouted in Chinese cities following the arrival in March of the Comintern representative Gregory Voitinsky, which initiated the founding of the Communist Party. Anarchists were initially quite prominent in these societies. They constituted the majority in the Beijing Society for the Study of Marxist Theory. In Guangzhou, the "Marxist" group consisted initially entirely of anarchists and two Comintern advisers. Anarchists also assumed the responsibility in these groups for the crucial task of editing the labor journals which the groups initiated. ${ }^{9}$

These societies were to provide the building blocks for the Communist Party of China. During Fall 1920, starting with Shanghai, Marxist study societies began their conversion into Communist cells. While the Communist Party was not founded officially until July 1921, by November 1920, an embryonic party organization had come into existence. The new organization adopted Bolshevik rules for its operation, and a Bolshevik program the cornerstone of which was to create a "dictatorship of the proletariat". Anarchists, who were opposed both to hierarchical organization and to proletarian dictatorship, abruptly left the organization. At the same time, the organization of the Party gave rise to the first polemics between Communists and anarchists the basic goal of which was to draw a clear distinction between the two philosophies of social revolution.

The organization of the Communist Party, with its demand for exclusive loyalty to the Party and its ideology, inevitably split the social revolutionary

${ }^{8}$ Zheng, "Wuzhengfu zhuyi", pp. 191-192.

9 Arif Dirlik, Origins of Chinese Communism (New York, 1989), for a more detailed discussion of these activities. 
alliance of the previous year. Nevertheless, the split was not finalized until sometime in the Spring of 1922; even then, efforts to overcome differences between Communists and anarchists were not completely abandoned. Anarchists were among those invited to attend the Congress of the Toilers of the East in Moscow in Spring 1922 and, according to Huang Lingshuang, Chen Duxiu told him in the Summer of 1922 that, "anarchists and communists are the leaders of reforming society; they can only advance in unity, and should not be divided to oppose one another". ${ }^{10}$ His offer was probably not made out of open-mindedness. Anarchist popularity was still on the rise in 1922 (it would peak in 1922-1923), and the First National Labor Congress recently convened in Guangzhou had just revealed the extent of anarchist influence in labor organizations in the South. Some among the anarchists continued to harbor hopes that Communists could be brought around to the anarchist cause, or at least to cooperate with anarchists. Anarchists who felt close to the Communist cause refused to abandon hopes of "anarchistBolshevik cooperation" (anbu hezuo or anbu xishou, literally, hand-inhand) and as late as 1923, in the last installment of his polemics with Chen Duxiu which had gotten under way in 1920, Ou Shengbai wrote: "Under the evil circumstances of present-day Chinese society, Marxists and Kropotkinists will both do. Let each seek in its own way to overthrow the forces of old society. We can resolve the question of social organization in practise when the time comes."11

Anarchists could see the writing on the wall, but they were reluctant to read it. Chinese anarchists were not much different in this regard from anarchists such as Emma Goldman and Alexander Berkman, who continued to harbor hopes against all available evidence (which they witnessed at first hand) that the Bolshevik leadership would come around to the original promise of a popular social revolution once the crisis of the new Soviet state had been averted; anarchists, like other socialists, had invested a great deal in the October Revolution as the beginning of a new age in history, and were unwilling to abandon hopes in its promise. Indeed, the final repudia-

10 "Lingshuang zhi mojun han" (A Letter from Lingshuang), Chunlei yuekan (Spring Thunder Monthly), 1 (10 October 1921), pp. 96-120, p.105. Huang himself displayed a peculiar uncertainty toward Bolshevism at this time. In its 1 July 1922 issue, Xin qingnian (New Youth), by then a communist organ, published a letter from Huang to Chen where the former wrote: "Although I have been uncertain in the past, I have come to believe firmly that this method [i.e. the dictatorship of the proletariat] is the only possible method of social revolution at the present; henceforth, I will strive to achieve humanity under your leadership." Until his open letter appeared in 1923, anarchists feared that they had lost one of their leaders to communism. Huang gradually dropped out of anarchist ranks after he went to the US.

"Ou Shengbai, "Da Chen Duxiu jundi yiwen" (Answering Mr. Chen Duxiu's Doubts), Xuehui (Sea of Learning), 104-109 (February 1923), in Ge et al., Wuzhengfu zhuyi sixiang, II, pp. 648-664, p. 664. 
tion of Bolshevism by Goldman and Berkman had much to do with Chinese anarchists' loss of hope in an alliance with the Communist Party in 1922. In the polemics against the Soviet Union and Bolshevism that Chinese anarchists launched after 1922 , their writings were to play a crucial part. For their part, the Communists and their Comintern advisers would seem to have dropped their quest for converting anarchists once they had found more powerful allies in the Guomindang. The effort to convert individual anarchists never stopped, but anarchists were only a barely visible Communist concern after the party embarked on founding a united front with the Guomindang in late 1922.

\section{Anarchist organizational activity in the 1920s}

In early 1922, anarchists once again turned their attention to organizing an independent anarchist movement. With the rise in popularity of anarchism during the May Fourth Movement, anarchist societies had proliferated all across China. While Guangzhou anarchists retained a leading role in the anarchist movement, moreover, increasingly anarchists from other parts of China, especially from Hunan and Sichuan, distinguished themselves as leading voices.

The nationwide diffusion of anarchism even further decentralized the anarchist movement, and makes it more difficult than earlier for the historian to identify a center to Chinese anarchism. It is possible, nevertheless, to point to a number of anarchist societies at this time if not as leaders at the least as clearinghouses in the propagation of anarchist ideology, and for the part they played in setting the tone for anarchist activity. These societies were distinguished for their longevity (and, therefore, the part they played in sustaining anarchist activity), the originality and intensity of their activities, and the general esteem in which anarchists across the country held the individuals who played leading roles in them.

In Spring 1922, "more than fifty" anarchists met in Guangzhou to establish an "Anarchist Federation" (described simply as "AF"). Earlier prominent Guangzhou anarchists had met with Chen Duxiu and other Communist leaders in Guangzhou to discuss the possibility of cooperation; the Federation may have been founded in response to the hopelessness of compromise between the two groups. The Federation's leadership included Ou Shengbai, Liang Bingxian and Huang Lingshuang, the most prominent among Guangzhou anarchists. A key role was played in the organization by a certain Russian who had recently appeared in Guangzhou, Dikebuo (Dikebov?), who apparently suggested the founding of a federation. The federation was organized as a secret conspiracy, complete with code names and passwords. ${ }^{12}$

12 "Benshe zhi gedi tongzhi han" (A Letter from This Society to Comrades Elsewhere), 
The federation did not last very long. The "barbaric" behavior of Dikebuo, who sought to assume dictatorial powers, and the fickleness of other members (by 1923 Ou Shengbai was in Paris and Huang Lingshuang at Clark University in Massachusetts) brought it to a quick end by Fall 1922.

Anarchists, however, did not give up. By August 1923, they had established a new federation, based around the Reality Society (Zhenshe).$^{13}$ Founded by the anarchists Wang Siweng, Li Shaoling, Zheng Zhenheng and Xie Juexian, Reality Society began publication in October 1923 of a new journal, Spring Thunder (Chunlei), which with some metamorphoses would serve for two years as an important organ of Chinese anarchism. The new federation had two important sections, a general work section and a propaganda section. The latter was subdivided into three areas that reflected the concerns of federation work: peasant, worker and education bureaus.

Very closely associated with these activities was another Guangdong anarchist society that had come into existence in 1922, the People's Tocsin Society (Minzhong she) led by Li Shaoling and Li Jianmin. At first a local society, this society had expanded its scope in response to the founding of the first federation in 1922. The journal that the society began to publish in July 1922, People's Tocsin, would have the privilege of being the longestlived (uninterrupted) journal in the history of Chinese anarchism. It was published for five years to the month, mostly in Guangdong until it was moved to Shanghai in the Spring of 1927. In later years, Bi Xiushao, Fang Juntian and Li Taiyi played important parts both in the society and the journal. The contributors to the journal included the most important of Chinese anarchists in the 1920s: Ou Shengbai, Huang Lingshuang, Liang Bingxian, Li Feigan (Ba Jin), Qin Baopu, Jing Meijiu, Wei Huilin and others whose names appeared frequently in anarchist publications but are not identifiable beyond the pseudonyms they employed (Kuli and Zhiping). Its special issues on Kropotkin in 1923 and Shifu in 1927 were landmark events in anarchist eyes, and drew contributions not only from the above but from the doyens of anarchism, Li Shizeng and Wu Zhihui. It was not only an important organ in the anarchist criticism of Communism, but also the foremost source at the time of the writings of European anarchists such as Proudhon, Bakunin, Kropotkin, Jean Grave and Varlaam Cherkezov.

When the Anarchist Federation had been established in 1922, it had sent Huang Lingshuang to Shanghai to bring anarchists there into the Feder-

Chunlei yuekan, 1 (10 October 1923), pp. 92-95 for this account. See also Zheng, "Wuzhengfu zhuyi", p. 201.

${ }^{13}$ This could also be translated as Truth Society. I use Reality Society here to distinguish it from the other Truth Society (Shishe). 
ation. The group Huang contacted in Shanghai (which was involved mainly in the teaching of Esperanto) included two Guangzhou anarchists, Zheng Peigang and Liu Wudeng (Shifu's sister and Zheng's lover), as well as Deng Mengxian and a woman anarchist from Hunan, Zhou Dunhu, a labor organizer and associate of Huang $\mathrm{Ai}$ and Peng Renquan who had recently been murdered for their labor activities. In 1923, this group started publishing its own journal, the short-lived Mutual Aid (Huzhu) edited by Deng Mengxian, as part of Federation activity. They also participated in the revival of Freedom (Ziyou) edited by Jin Meijiu, which had been suspended by the authorities in 1922 . Freedom Society would also serve in ensuing years as a source of anarchist literature. ${ }^{14}$

The Anarchist Federation also corresponded with the Paris anarchist journal, After Work (Gongyu) which between 1922 and 1925 was an important anarchist organ in the polemics against the Communists in France. It was edited at first by Chen Duxiu's sons who, until their conversion to Communism in 1923, led the polemics against their father's party (represented in Paris by Youth (Shaonian), in which Zhou Enlai defended Bolshevism against the anarchists). After 1923, Li Zhuo and Bi Xiushao played an important part in this journal. In 1925, when $\mathrm{Bi}$ returned to China, After Work was merged with Free People (Ziyou ren), edited by Shen Zhongjiu who, like $\mathrm{Bi}$, was from Zhejiang province..$^{15}$ (Bi also became the editor, briefly, of People's Tocsin when it was moved to Shanghai.)

Three other societies, which were at best loosely connected with Guangzhou anarchists and the Federation, were to play important roles in the anarchist movement either as disseminators of anarchism or as nodes of anarchist activity. First was the Free People Society (Ziyon she) founded in Shanghai in 1924, led by the Zhejiang anarchist Shen Zhongjiu and a Chinu (a pseudonym). The importance of this society derived above all from its involvement in the syndicalist movement in Shanghai. Members of the society were active in the syndicates and in labor education. They were involved in, if they did not initiate, a syndicate periodical Labor Ten-daily (Laodong xunkan). Shen worked closely with Hunanese anarchists who were an important force in the Shanghai Federation of Syndicates (Shanghai gongtuan lianhe hui). He was also a teacher at the experimental Lida School established in Shanghai at this time by the Hunanese anarchist Kuang Husheng. It was possibly out of this association that a plan emerged at this time to establish a Labor University (Laodong daxue), which was realized three years later. The Free People Society corresponded with

14 Zheng, "Wuzhengfu zhuyi", p. 202.

15 Bi Xiushao, "Wo xinyang wuzhengfu zhuyidi qianqian houhou" (Account of My Anarchist Beliefs), in Ge et al., Wuzhengfu zhuyi sixiang, II, pp. 1022-1938, p. 1025. 
Spring Thunder in Guangzhou and would, in 1925, merge with After Work (of these activities, more below). ${ }^{16}$

A second important society in Shanghai was the People's Vanguard Society (Minfeng she), in which the Sichuan anarchists Lu Jianbo and Mao Yibo played leading roles. The society was established in Nanjing in 1923, and published there a journal of the same name before moving to Shanghai in 1925. Lu had earlier been active in anarchist activities in Sichuan, and had some association in Shanghai with his more famous fellow-provincial Ba Jin, who also had moved to Shanghai in the mid-twenties. Lu was responsible for founding two societies in 1927 that played some part in anarchist activity in Shanghai, the Society for the Study of Syndicalism (Gongtuan zhuyi yanjiu hui) and the Federation of Young Chinese anarcho-communists (Zhongguo shaonian wuzhengfu gongchan zhuyizhe lianmeng). He had to leave Shanghai in 1928 to escape persecution by the Guomindang because of his criticism of anarchist-Guomindang cooperation (he was accused by Guomindang related anarchists of being a "Bolshevized-anarchist!'). In the late thirties, he was back in Sichuan, publishing another anarchist periodical. ${ }^{17}$

Finally, the most active anarchist society in Northern China was the Sea of Learning Society (Xuehui she) which published a supplement of the same name to the National Customs Daily (Guofeng ribao), edited by the Shanxi anarchist Jing Meijiu. One of the elders of Chinese anarchism at the time, Jing had converted to anarchism in Tokyo in the days before the 1911 revolution. Jing possibly had been influenced by the agrarian anarchism that the Tokyo anarchists had propagated. In addition to disseminating anarchism in the North, members of the Sea of Learning Society were also active in the promotion of anarchism in rural areas. ${ }^{18}$

Future research may reveal that other anarchist societies played equally, possibly more, important roles in the anarchist movement in the 1920s. Anarchists were active everywhere, involved in their own organizations as well as organizations of others who nevertheless gave the anarchists room in their own publications (such as the supplement to the Current Affairs Daily (Shishi xinbao) of the anti-revolutionary Research Clique, Light of Learn-

16 "Tongzhi xiaoxi" (News of Comrades), Jingzhe (Spring Festival; literally, "the awakening of insects"), 1 (1924). This journal was a continuation of Chunlei, after the latter was shut down. See also Zheng, "Wuzhengfu zhuyi", pp. 204-206.

${ }^{17}$ Jiang Jun, " $\mathrm{Lu}$ Jianbo xiansheng zaoniandi wuzhengfu zhuyi xuanchuan huodong jishi" (An Account of Mr. Lu Jianbo's Anarchst Activities in His Youth), in Ge et al., Wuzhengfu zhuyi sixiang, II, pp. 1009-1022. "Fangwen Fan Tianjun xianshengdi jilu" (Account of a Visit with Mr. Fan Tianjun) in ibid., pp. 1039-1048; pp. 1041-1043 discusses some of the activities of this radical group.

${ }^{18}$ Jing Meijiu, "Zuian" (Account of Crimes), in Chinese Academy of Social Sciences (ed.), Xinhai geming ziliao leipian (Materials on the 1911 Revolution) (Beijing, 1981), pp. 54-157. 
ing (Xuedeng), which was an important forum for anarchist writings on the Soviet Union). Their activities ranged from the distribution of anarchist pamphlets whenever an occasion presented itself to more sustained ideological activity, as well as organizational activities among labor and the agrarian population. ${ }^{19}$

The dispersed nature of these activities makes risky any generalizations concerning these societies or their relationship to one another. What distinguished the societies above was the sustained nature of their activities, which made them somewhat more visible as nodes of activity. We need to emphasize here that in spite of their assumption of such appellations as "federation", these societies, too, were largely independent of one another in their activities. What gave them some semblance of unity was the correspondence in which they engaged, and relatively frequent contact between those who played leadership roles within them. In the end, for these societies, as well as for numerous others both in rural and urban China, what made anarchism into a movement was the motion of individual anarchists, often but not always along the same general direction. If there was one thing that above all unified the anarchists, it was their opposition to Bolshevism. The challenge of Bolshevism was also responsible, ironically, for shaping the anarchist pursuit of revolution.

\section{Anarchists and the critique of Bolshevism and Marxism}

In the years 1918-1920, Chinese anarchists like anarchists elsewhere exhibited considerable ambivalence toward Bolshevism. The initial anarchist response to the October Revolution was one of enthusiasm, which was responsible not only for creating a favorable impression toward the Revolution among radicals, but also for suggesting to some that the Bolsheviks were guided by anarchist intentions. By early 1919 , as news of the Bolshevik suppression of anarchists reached the outside world, anarchist reports grew more somber. A piece in the anarchist journal Evolution accused the Bolsheviks of "piratism", denying that the Bolsheviks were socialists because to call them socialists would be to allow that socialism permitted "people to eat one another". Others in 1919 objected to the Bolshevik promotion of class struggle because, they believed, it betrayed the humanitarian goals of revolution. These criticisms were sporadic, however, and other anarchists were quick to rush to the defense of Bolshevism. While Bolshevism fell short of the ideals of social revolution, they argued, under contemporary circumstances it provided the only viable model of revolu-

19 These activities may be gleaned from the "News of Comrades" sections published in anarchist journals. For a sample from People's Tocsin, see Zhao Chonghou et al. (ed.), Wusi shiqidi shetuan (Societies of the May Fourth Period), 4 vols (Beijing, 1979), IV, pp. 275-280. 
tion; anarchists should defend the revolution and help move it along the path of a true social revolution. Whatever qualms anarchists may have had concerning Bolshevism, these did not stop them from propagating favorable news of the Revolution or even responding positively to the first Comintern overtures in China. ${ }^{20}$ Their differences were as much a function of internal differences over the conception of social revolution, and the foreign sources to which they had access, as they were of the conflicting evidence issuing from the Soviet Union.

Anarchist criticism of Bolshevism gained in consistency - and urgency following the establishment of a Communist organization in late 1920 , which was accompanied by extensive attacks on anarchism by the leaders of the new organization, who sought thereby to draw a clear distinction between anarchism and Marxism to purge the new organization of lingering anarchist influences, and to undermine the credibility of anarchism which still exerted a pervasive influence among radicals. Ou Shengbai, who undertook to defend anarchism against these attacks, was to engage Chen Duxiu, the leader of the Communist organization, in a debate that lasted well over a year, and laid down the agenda for anarchist criticism of Bolshevism over ensuing years.

This debate was conducted in a relatively friendly tone, partly because of the close personal relationship between the two men, but also because among the anarchists, Ou Shengbai came closest to accepting a Marxist analysis of society. It is also possible that anarchists held back their criticism of Bolshevism so long as further cooperation with the Communists remained a possibility. After 1922, when the break between the two groups became evident, anarchist criticisms would assume a much harsher tone.

While internal developments in revolutionary politics would play an important part in shaping anarchist attitudes toward Bolshevism, their criticism of the Soviet Union and Marxism was derivative almost in its entirety of foreign anarchists' writings on the subject. Indeed, the latter's disillusionment with the Soviet Union may have played a significant part in the increasingly intransigent repudiation of Bolshevism by the Chinese anarchists. With the conclusion of the crisis in the Soviet Union that had been caused by foreign aggression and internal insurrection, and the end of "War Communism" which ushered in the New Economic Policy, it was no longer possible for anarchists to blame the shortcomings of Bolshevik socialism on external causes. Such was the case with Emma Goldman and Alexander Berkman who left the Soviet Union in 1921 in final disillusionment. Their attacks on the Soviet Union thereafter left a deep impression upon Chinese anarchists; it may even be suggested that the writings in particular of Emma Goldman, which were broadly circulated in China, and

${ }^{20}$ For a discussion of these relationships in detail, see Dirlik, Origins, chs 2 and 10. 
her personal contacts with Chinese anarchists were responsible in large measure for shaping Chinese anarchists' attitudes toward the Soviet Union. Equally important was the testimonial against the Bolshevik government of Russian anarchists. Mme. Kropotkin's criticisms of the Bolsheviks provided an authoritative voice in Chinese criticisms of the Soviet Union (Kropotkin himself had died in early 1921, relieving the anarchists who had been concerned about his safety of the need for caution in their criticisms). Most important, however, were the writings of Varlaam Cherkezov, a Georgian anarchist who had long been a close associate of Kropotkin's. ${ }^{21}$ Before his death in 1925, Cherkezov wrote extensively on Marxism, to which he traced the failings of the Bolsheviks. His writings were translated into Chinese, and incorporated freely into Chinese criticisms of Marxism. If Goldman shaped anarchist views on the Soviet Union, Cherkezov provided them with a theoretical perspective which extended the critique of Bolshevism to a criticism of its roots in Marxist theory.

\section{Bolshevism and the distortion of revolution}

The Chinese who led the way in the criticism of Bolshevism and Marxism after 1922 either had personal experience of the Soviet Union and/or were personally acquainted with foreign anarchists critical of Bolshevism: Huang Lingshuang, Qin Baopu, Bi Xiushao and Ba Jin. Huang's experiences in the Congress of the Toilers of the East in early 1922, as well as his contacts with Russian anarchists (including a visit with Mme. Kropotkin), convinced him of the "bankruptcy" of Bolshevism; he resolved even before his return to China that the Chinese public should be informed of the true visage of Bolshevism. ${ }^{22} \mathrm{Bi}$ Xiushao, who was in France 1920-1925, was acquainted not only with prominent French anarchists such as Jean Grave, but met Mme. Kropotkin when she was in Paris in $1923 .{ }^{23}$ Qin Baopu played an especially important part in these criticisms. Qin had been a student in the Soviet Union between 1920 and 1923, sent there ironically with the first contingent of Chinese students to study in the Soviet Union in preparation for the founding of the Communist Party. While there, he had extensive contacts both with Goldman and Mme. Kropotkin as well as with other Russian anarchists. Upon his return to China in 1923, he was responsible for introducing Goldman's writings to the Chinese public, as well as authoring himself a number of articles (and a book-length account of the Soviet Union) critical of Bolshevism. He was also responsible for introducing Goldman to Ba Jin. Ba Jin, who entered a correspondence with Goldman at this time that would last until her death, emerged quickly in the mid-

${ }^{21}$ Paul Avrich, The Russian Anarchists (Princeton, 1978), pp. 39-40.

22 Huang, "Letter", pp. 110-111.

${ }^{23} \mathrm{Bi}$, "Wo xinyang wuzhengfu zhuyi", pp. 1025-1026. 
twenties as a prolific translator of foreign anarchist works into Chinese, including works by Goldman and Berkman. He himself was the author of a number of pieces sharply critical of Bolshevism. ${ }^{24}$

These anarchists were by no means the only ones to engage in polemics against Bolshevism; they are singled out here because of the strategic role they played in introducing to China the writings and the views of foreign anarchists. As noted above, the agenda for Chinese anarchist criticisms of Bolshevism was set in 1920-1921, in Ou Shengbai's polemics with Chen Duxiu. The major issues of debate in these polemics had been the dictatorial organization of the nascent Communist Party, and the inclusion in its program of the "dictatorship of the proletariat" as an immediate goal. Ou, voicing the feelings of many anarchists, had argued against this program that a genuine social revolution could be achieved only through voluntary association, which would guarantee to the revolution the accomplishment of its goal of a free communist society. Key to his conception of revolution was a transformation of social consciousness in the process of revolution, which would obviate the need for coercion when the revolution finally came about. Ou believed, with other anarchists, that the goal of revolution was not to create a new class rule but to abolish classes altogether (which would also eliminate the need for the state and politics since he believed, with Marxists, that the state was a product of class conflict); the "dictatorship of the proletariat" would merely end up reproducing the evils of old society. ${ }^{25}$

Anarchist criticism of Bolshevism after 1922 further developed these objections. Anarchists rejected that the Bolshevik revolution constituted a genuine social revolution, and portrayed it instead as a political revolution that had merely brought a new group into the control of an old-fashioned state. Huang Lingshuang recalled Mme. Kropotkin telling him that Bolshevik socialism was not real socialism because real socialism could not be built upon a centralized state power (this, according to her, had been Kropotkin's view before his death) ${ }^{26}$ The declaration against anarchist-Bolshevik cooperation of a Red Society (Hongshe) in 1923 stated that in order to achieve the goal of revolution, another revolution would be necessary to overthrow this new power structure, which merely increased the number of revolutions necessary to achieve socialism, and would lead unnecessarily to further sacrifice and bloodshed: "If we are to rely on Bolshevism as a transitional stage in moving from present society to anarchist society, it

${ }^{24}$ Qin Baopu, "A Memoir of My Meeting Ms. Goldman in Russia in My Early Days" (Original Chinese), Letter to Prof. Lu Zhe (1987?). I am grateful to Candace Falk (ed.), "The Emma Goldman Papers", University of California-Berkeley, for sharing with me this letter, as well as other materials on Goldman's relationships with Chinese anarchists.

${ }^{25}$ For a more detailed discussion of these polemics, see Dirlik, Origins, ch. 10.

${ }^{2}$ Huang, "Letter", p. 110. Bi also heard this in person from Mme. Kropotkin. "Wo xinyang wuzhengfu zhuyi", p. 1025. 
means that we have to go through two revolutions, one to achieve Bolshevism and another to achieve anarchism. Is this not a great sacrifice?"27

The central anarchist objection to Bolshevism was over the issue of the "dictatorship of the proletariat". In the last installment of his polemics with Chen, Ou Shengbai had observed that what the revolution ought to abolish was not merely oppressors but oppression itself, since as long as oppression existed, it did not matter who did the oppressing.$^{28} \mathrm{Ba}$ Jin described the "dictatorship of the proletariat" as mere "revanchism", which not only did not create a better world but opened the way to further conflict since, if workers became the new dictators, others would seek to overthrow them. Besides, he argued, the term "dictatorship of the proletariat" was a meaningless term because "at the present the proletarian class constitutes the majority in society, and there has been no such thing historically as a majority oppressing a minority". ${ }^{29}$ As early as 1921, an unattributed piece in People's Voice observed, rather cleverly, that if the proletariat following the overthrow of the bourgeoisie itself climbed the "political stage" as its ruler, it would no longer be the proletariat (literally, common people, pingmin)..$^{30}$

In his report on the Soviet Union, Huang had observed that the so-called "dictatorship of the proletariat" was nothing but a mask for a dictatorship of intellectuals in the Communist Party. ${ }^{31}$ Sanbo (Bi Xiushao?) added in his polemics with Zhou Enlai in Paris that the "dictatorship" was nothing but the dictatorship of a single party and, within the party, of a few leaders; it ought to be called in reality a "dictatorship of the leaders of the Communist party". ${ }^{32}$ As Lu Jianbo put it in an extensive discussion of the "dictatorship of the proletariat" published in Light of Learning in 1924: "Facts tell us: the inner lining of the dictatorship of the proletariat is the dictatorship of a single party - the Leninist Party. The Soviets have already been captured by bureaucratic socialists. "33 Anarchists found ample evidence of this dictator-

27 "Fandui anbu xishou xuanyan" (Declaration Opposing Anarchist-Bolshevik Cooperation), Xuehui, 109 (5 February 1923), in Ge et al., Wuzhengfu zhuyi sixiang, II, pp. 665-666, p. 665.

${ }^{28}$ Ou, "Da Chen Duxiu", p. 658.

${ }^{29} \mathrm{Li}$ Feigan (Ba Jin), "Zailun wuchan jieji zhuanzheng" (Another Discussion of the Dictatorship of the Proletariat), Xuedeng (Light of Learning), 17 (1925), p. 1.

${ }^{30}$ "Wuzhengfu gongchanpai yu jichan paizhi qidian" (Differences Between Anarchocommunists and Collectivists), Minsheng (People's Voice), 30 (March 1921), in Ge et al., Wuzhengfu zhuyi sixiang, II, pp. 565-566.

${ }^{31}$ Huang, "Letter", p. 113.

32 "Iguo gongchan zhuyi shibaizhi yuanyin jiqi buqiudi fangfa" (The Failure of Communism in Russia and the Way to Salvage It), Gongyu (After Work) (September 1922), in Ge et al., Wuzhengfu zhuyi sixiang, II, pp. 595-601, p. 598.

${ }^{33}$ Jianbo, "Lun wuchan jieji zhuanzheng" (On the Dictatorship of the Proletariat), Xuedeng, 20-22 (1924). See no. 20, p. 1. 
ship not only in the suppression by the Bolsheviks of other revolutionaries (the anarchists in particular), but also in the readiness of the Soviet government to turn its guns on the people, as in the Kronstadt rebellion of $1920 .{ }^{34}$

Political dictatorship, anarchists believed, was exacerbated by the economic dictatorship of the state; in the failure of Bolshevik socialism, "political centralization" (jiquan) was the other side of the coin to "economic collectivism" (jichan). Chinese anarchists had since the mid 1910s drawn a distinction between "collectivism" and "communism" (gongchan). Anarchism was truly communist, Marxian communism was in essence collectivist. The failure of Bolshevik socialism, they now argued, rested not only in its repudiation of democracy for dictatorship, but in its economic basis in state collectivism which was merely "capitalism in a different form", ${ }^{35}$ since all it accomplished was to replace ownership by individuals by ownership by the state. This new form of ownership exacerbated the exploitation of the people since the state now had a monopoly over employment and could set its terms as it pleased. The anarchist argument was summarized by $\mathrm{Ou}$ Shengbai in a cogent statement:

Marxian socialism advocates not only the centralization of political power but also of capital. The centralization of political power is dangerous enough in itself; add to that the placing of all sources of wealth in the hands of the government, and the so-called state socialism becomes merely state capitalism, with the state as the owner of the means of production and the workers as its laborers, who hand over the value produced by their labor. The bureaucrats are the masters, the workers their slaves. Even though they advocate a state of the dictatorship of workers, the rulers are bureaucrats who do not labor while workers are the sole producers. Therefore, the suffering of workers under state socialism is no different from that under private capitalism. Besides, while the power of individual capitalists to exploit the worker is relatively limited, the state can back up its exploitation with military force; hence the wretchedness of the worker at the very least equals that under capitalism. ${ }^{36}$

Ironically, anarchists perceived in the relaxation of economic controls with the New Economic Policy a confirmation of their view that Bolshevism was but a transmuted capitalism. Qin Baopu, who wrote extensively on this issue, found in the Bolshevik call on foreign capital to help develop the Soviet Union evidence of collusion between Bolsheviks and foreign capitalists against the interests of the people; the Bolsheviks, he believed, were less concerned about the people and socialism than they were with the

34 Ibid., see also Li, "Zailun wuchan jieji".

35 Jianbo, "Lun wuchan jieji zhuanzheng"; Baopu, "Makesi zhuyi piping" (Critique of Marxism), Xuedeng, 19 (1924).

${ }^{36} \mathrm{Ou}$, “Da Chen Duxiu”, p. 663; Sanbo, "Iguo gongchan zhuyi”, p. 599. 
economic development of the state. ${ }^{37}$ The Communist alliance with the Guomindang in China was to provide anarchists with additional evidence of the essentially "capitalist" nature of Marxian socialism.

\section{The critique of Marxism}

As these criticisms suggest, the anarchist critique of Bolshevism, of its economic policies as well as its stance on the question of classes, implicated Marxism in the failure of Bolshevik socialism. Some continued to blame the failure of socialism in Russia on the backwardness of Russian society which, as an agrarian society, did not fulfill the conditions upon which socialism could be built.$^{38}$ Increasingly, however, anarchists traced the failure of the revolution to its Marxist premises. Cherkezov's analyses of Marxism provided them with the theoretical weapons they needed. It might be noteworthy here that in spite of a measure of simplification, these writings presented an analysis of Marxism that was more sophisticated than any other available in China at the time, including to the Communists whose understanding of Marxism was shaped almost exclusively by a Leninist interpretation.

As it appeared in Chinese anarchists' writings (which for the large part consisted of rephrases of or direct quotations from Cherkezov), Marxism suffered from a fatal ambivalence which had entered the theory at its very origins. It shared with all socialism, including anarchism, a vision of the future in which society would be "managed by free associations of workers" and peasants' organizations" (Gongnong zuzhidi ziyou xieshe gongtong guanli).$^{39}$ At the same time, however, the method that the theory suggested for reaching this goal compromised its vision irredeemably, since all of the key concepts that Marx had utilized to formulate his theory - hence the theory itself - were derivative of the ideas of bourgeois economists and philosophers, which meant that his methods were shaped by the premises and prejudices of bourgeois society. Marxism, in other words, suffered from a fundamental contradiction between its socialist vision, and a method for reaching that vision that was thoroughly infected by bourgeois ideology.

${ }^{37}$ Baopu, "Xin jingji zhengce" (New Economic Policy), Xuedeng (January-February 1924), in Ge et al., Wuzhengfu zhuyi sixiang, II, pp. 854-859.

${ }^{38}$ Huang, "Letter", p. 112; Sanbo, "Iguo gongchan zhuyi", pp. 596-597.

${ }^{39}$ The discussion below is based on a long essay by Lu Zhi, "Makesi zhuyi piping" (Critique of Marxism) which was a combination restatement/translation of Cherkezov's work. Lu says in his postscript that the essay was first published in Minzhong. The version used here is from part 5 ("Makesi zhuyidi pochan" (Bankruptcy of Marxism)) of Ziyou congshu (Compendium on Freedom), pp. 151-228. This was a valuable collection of anarchist writings from the twenties (mostly translations) published in 1928 by the Equality Society (Pingshe) in San Francisco. The Compendium was first published in Shanghai by the Freedom Bookstore (Ziyou shudian) in 1927. 
The method itself, moreover, contained a contradiction: between a tendency that was social democratic but reformist, and a tendency that was revolutionary but Jacobinist (hence divorced from the people). However different from one another, neither of these methods broke with bourgeois politics.

While these writings insisted that Marx had lacked originality as a social thinker since he had received all of his theoretical insights from others, they nevertheless recognized to him considerable complexity, drawing a distinction between a young Marx and a mature Marx in terms of his attitude toward the state. In his earlier writings, including the Communist Manifesto, Marx had privileged the state as an agent of change, and seen in the socialist capture of the state the key to bringing about socialism. The Paris Commune had constituted a turning point in Marx's thinking. It had inspired him to a new view of socialism as "a federation of free associations" (ziyou zuzhidi lianbang). Thereafter, he had abandoned his former reliance on the state as the agent of socialism. While in his Critique of the Gotha Program he had once again turned to the theme of the "dictatorship of the proletariat", it was not clear whether he meant by this a "dictatorship of the state", as some Marxists claimed, or a dictatorship of the people after the example of the Commune.

If there was a "villain" in the account, it was Engels. It was Engels who had elevated Marx to the status of a creative genius, therefore covering up Marx's intellectual debt to bourgeois scholars. It was Engels who had sought to synthesize the irreconcilable philosophical ideas of materialism and the dialectic into a "dialectical materialism" which he then presented as a science (which, Cherkezov argued, distorted Marx because it privileged the deductive method over the inductive method that Marx had favored, and restored to Marxism the Hegelian metaphysics which Marx had repudiated). Finally, Engels had been responsible for restoring to Marxism its pre-Paris Commune prejudice for the state by once again privileging the state as an agent of change. In the process, he had also taken revolution out of Marxism and made it into a strategy of peaceful change.

Engels, in other words, appeared as the immediate source of contemporary social democracy. Lenin had broken with Engelsian Marxism both in his insistence on violence and in his elevation of the idea of proletarian dictatorship. He, too, however, had departed from the post-Commune ideas of Marx. Rather, his approach to Marxism had revived the Jacobinist tradition, which reduced the real revolutionaries - workers and peasants to mere appendages to the revolution. While the Bolsheviks sought to represent themselves as champions of the people by claiming the Soviets for their own, this had little basis in reality for the Soviets had been anarchist in inspiration and origin. Lenin's socialism, Cherkezov concluded, was but a "modified state capitalism", concerned primarily to carry out the task of 
economic development that in advanced countries had been accomplished by the bourgeoisie.

This portrayal of Marxism was itself quite reductionist in some of its key conclusions; nevertheless, it raised questions concerning Marxism that retain their significance to this day and, in the context of China in the 1920s, was without parallel in sophistication. The questions it raised concering the relationship of Marxism to its bourgeois legacy, the role Engels played in the formulation of Marxism after Marx, and especially the meaning of the "dictatorship of the proletariat" in the post-Commune writings of Marx were basic issues which are debated to this day. Cherkezov, moreover, backed up his arguments with an extensive coverage of Marxist and nonMarxist literature that was very impressive for its grasp of fine details in the history of Marxism.

The issues Cherkezov raised quickly assumed nearly formulaic status in anarchist discussions of Marxism, as may be gleaned from an article by Shen Zhongjiu published in People's Tocsin in early $1927 .{ }^{40}$ Shen raised six objections to Marxism: (a) Marx had copied his most basic ideas from others: class struggle (Guizot, Considerant, Blanc, Proudhon), the concentration of capital (Considerant), surplus value (Sismondi, Blanqui), rate of profit (Ricardo), historical materialism (Vico, Herder); (b) Marxism is utopian, not scientific because science is based on the inductive method whereas Marxism is metaphysical; hence its errors on such questions as the concentration of capital, or its inability to account for the role consciousness plays in society because of its assumption of technological determinism, which ignores that it is human consciousness that creates technology; (c) Marxism advocates private property; the state takes over production and remunerates individuals according to their contribution, which turns everyone into a capitalist; (d) Marxism is reformist, not revolutionary; (e) Marxism advocates dictatorship of the few; and (f) Marxism stresses industry and ignores agriculture; hence it is irrelevant to China. The last item, which will be discussed further below, was a particularly Chinese concern; the rest were merely summaries of Cherkezov's argument (as Shen acknowledged in his essay).

Two of the issues that Cherkezov raised were of particular importance in Chinese discussions of Marxism: the concentration of capital and class struggle. An essay of Cherkezov's on the former issue appeared in anarchist publications more than once, complemented by Chinese discussions on the subject. The essay argued, based on empirical data, that Marx had been wrong in predicting a progressive concentration of capital, and suggested to the contrary that the number of independent businesses had been on the

* Tianxin (Shen Zhongjiu), "Gao gongchandangdi qingnian" (To Communist Youth), Minzhong (People's Tocsin) 2.3 (25 March 1927), pp. 205-222. 
rise since Marx's time. Anarchists were impressed by Cherkezov's idea that Marx had copied this notion from other economists. More important, however, may have been the implications of the question for the future of socialism. In Imperialism: The Highest Stage of Capitalism Lenin had perceived in the concentration of capital a process that would facilitate the establishment of socialism; all the state needed to do was to take over from large corporations in order to convert a capitalist into a socialist economy. The proliferation of small enterprises would suggest, to the contrary, that state socialism could be established only by going against economic trends, which lent additional support to the anarchist critique of Bolshevism. Whether anarchists also perceived in this an argument in favor of anarchism is more difficult to say. ${ }^{41}$

The issue of class was more complex, if only anarchists were themselves divided over it. Some anarchists rejected it altogether because they viewed class struggle as another expression of selfishness in society which, in the social divisions it promoted, contravened the humanitarian goals of anarchism; this view of class would provide Guomindang related anarchists with an ideological weapon against the Communists in the late twenties. Others, while they were willing to recognize the importance of class, were nevertheless reluctant to attribute to it the centrality with which Marxists endowed it. An unattributed article published in People's Voice in 1921 argued that there was little reason to view all history as the history of class struggle, as Marxists claimed, because classes were not always distinguishable from one another in their interests, and even if class struggle at times moved to the center of history, it was not always central since other loyalties (such as national loyalty) took precedence over class loyalty. Most interesting was the "thought experiment" that the author suggested:

Suppose someone suggests another method of revolution on the basis of the three lines in the Communist Manifesto: 1 . Women of the world, unite; 2. Overthrow the present-day male political order; 3. [establish] a woman's dictatorship. Put simply, "male-female struggle, dictatorship of women". They also suggest that this is the method of social revolution, and the means to the transition to Communism. Should our social revolutionary method be the former (Marx's) or the latter (women's)? Or should we let each follow its own way? Whatever the choice might be, we think that people have no wish to heed this kind of theory. ${ }^{42}$

"1 Mao Yibo, "Makesizhi 'ziben jizhong' di miushuo" (The Erroneousness of Marx's 'Concentration of Capital'), Xuedeng (12 December 1925).

2 " 'Jieji zhanzheng' he 'pingmin zhuanzheng' guoshi yongyu shehui geming ma?" (Are 'Class War' and 'Dictatorship of the Common People' of Use in Social Revolution?), Minsheng, 13 (July 1921), in Ge et al., Wuzhengfu zhuyi sixiang, II, pp. 587-590, p. 590. A good discussion of the difficulties of class analysis was offered by Bibo (Bi Xiushao), “Jieji douzheng" (Class Struggle), Geming zhoubao (Revolution Weekly), 18(1927), pp. 244-249. 
It would be possible but erroneous to read this statement as derogatory of women; the struggle of women for liberation was after all a primary concern for anarchists, and a probable reason for questioning an exclusive focus on the proletariat. Rather, the point was to challenge the Marxist assumption of a central thread to history in class struggle and the consequent centering of the struggle for liberation on the proletariat. The goal, in other words, was to further open up the possibilities available in the struggle for liberation by denying to history a center.

Even those anarchists who took class struggle for granted, viewed it in terms slightly different than in Marxism; not as a function of the production process but rather in terms of rich and poor, those who lived off the labor of others and those who labored, or even the educated versus the uneducated. For anarchist advocates of class struggle, the concept was problematic, moreover, because of the relationship that the Leninist argument established between class and the dictatorship of the proletariat; while they conceded that class struggle was a basic datum of history, classes could not be allowed to exist after the revolution because this would mean the inevitable resurrection of the state. The revolution, in other words, must pursue a strategy that would not only abolish existing class oppression, but the very existence of classes. Ou Shengbai, who may have been closest to the Communists on the issue of class, explained:

I advocate class war because I believe that classes must be extinguished; if the ruled classes do not unite to overthrow the ruling class, the class system cannot be easily abolished. But I wish to use class war to abolish classes, not to overturn them as you [the Communists] do; most anarchists pursue the syndicalist movement and advocate class war. When I speak of the working class, it is the real working class; and not, as is the case with you, to organize a political party and view it as the working class, make the working class into a tool of the political party or make the party into a dictator over the working class. Although I have refrained from criticizing the system in Russia, there is much about it that is not satisfactory. Under the present capitalist system, capitalists are our mutual enemy, and instead of attacking one another, we must give one another support. But if you try to carry the Russian system to China in its entirety, I cannot go along with it. ${ }^{43}$

Anarchist objections to the dictatorship of the proletariat which we have already discussed further illustrate the ways in which anarchists found Communism to be wanting in its conception of the role of classes in revolution. Suffice it to say here that where this particular issue was concerned, Chinese anarchists had already elaborated arguments which they

${ }^{43}$ Ou, "Da Chen Duxiu", pp. 662-663. Other prominent proponents of class struggle were Liang Bingxian, and the Sichuan anarchists Lu Jianbo and Mao Yibo. 
now developed further in their criticisms of Marxism. The portrayal of Marxism by Cherkezov lent additional support to these arguments. Marx's views on class were lacking in authenticity, Cherkezov suggested, because they had been copied from others; they were "counterrevolutionary", because they were rooted in bourgeois conceptions of politics. Marx's only difference from his "teachers" Guizot and Lorenz von Stein, both of them defenders of private property and the bourgeoisie, had been that whereas they had justified the dictatorship of the bourgeoisie, he had argued for a dictatorship of the proletariat. Class struggle, which to the anarchists and syndicalists meant economic struggle for liberation, meant to Marxists a political struggle which in its basic conception differed little from bourgeois conceptions of the problem. ${ }^{44}$

\section{Anarchists and revolution in China}

For all their brave talk about the bankruptcy of Bolshevism and Marxism, anarchists were quite aware by the mid-twenties that they were inexorably losing ground to the Communists. The alliance with the Guomindang (formalized in early 1924) significantly increased Communist access to the mass movements. By the time of the second National Labor Congress in 1925, Communists had replaced anarchists in the leadership of the labor movement; their influence over labor would draw further force from the mass mobilization that followed the May Thirtieth Incident in 1925. Likewise their influence over youth and women's movements and, starting in 1925 , over the growing agrarian movement.

Anarchists themselves had the option of bringing their movement under the Guomindang umbrella. The Guomindang had its own ideology in Sun Zhongshan (Yat-sen)'s Three Peoples Principles, of course, but unlike the Communist Party it was loose organizationally, and accommodated disparate political positions under its ideological umbrella. As Shen Zhongjiu would write in 1927, the Three Peoples Principles were quite flexible in their broadness, and its emphases could change with changing circumstances. ${ }^{45}$ Besides, the doyens of anarchism in China, such as Li Shizeng and $\mathrm{Wu}$ Zhihui, were important members of the Guomindang; they now pressured their younger followers to join the Guomindang to compete with Communists.

After the Guomindang suppression of Communism in 1927, many anarchists would collaborate with the Guomindang under the slogan, "using the Three Peoples Principles as a means to achieve anarchism" (yi sanmin

44 Lu, "Makesi zhuyi piping", pp. 194-203.

45 "Fakan ci" (Opening Statement), Geming zhoubao, 1 (July 1927), pp. 3-17, p. 13. Shen was the editor and, according to Biu Xiushao, wrote this statement. He had earlier opposed alliance with the Guomindang. 
zhuyi wei shouduan, yi wuzhengfu zhuyi wei mubiao; literally, "take the Three People's Principles as method, anarchism as goal"). ${ }^{46}$ In the early twenties, however, the more activist among the anarchists, especially those connected with the Guangzhou and Sichuan anarchists, were reluctant to enter such an alliance. While anarchists collaborated with Guomindang labor leaders in the syndicalist movement in Shanghai in 1924-1925 (and possibly also in Guangzhou), because of their opposition to politics, they remained wary of any alliance with a political party. In 1912, Shifu had criticized Zhang Ji and Wu Zhihui for their participation in the Guomindang. His heirs now directed similar criticism at Wu Zhihui and Li Shizeng for their political activities.

Radical anarchists were also opposed to the nationalist goals of the revolutionary movement led by the Guomindang/Communist alliance. At the height of the nationalist movement in China, anarchists continued to criticize nationalism and patriotism as "obstacles to the progress of humankind", rooted in "selfishness and self-aggrandizement". They bemoaned the growth of patriotic sentiment since the May Fourth Movement, since they believed that nationalism inevitably strengthened the government, and built around people walls that separated them from one another. ${ }^{47}$ When Jean Grave in a letter gently rebuked Chinese anarchists for their inflexibility on this issue, reminding them that he and Kropotkin had supported World War I as a necessary compromise, Bi Xiushao (who had known Grave in France) responded that while anarchists were opposed to imperialism because of its oppressiveness, they could not support a nationalist movement that glorified patriotism. ${ }^{48}$

Beyond these issues of principle, anarchists opposed the Guomindang as a bourgeois organization that was counterrevolutionary in nature. Indeed, anarchists perceived in the Communist alliance with the Guomindang confirmation of their belief that Bolshevism was essentially bourgeois in orientation. In a long essay criticizing Communist rationalizations for joining the Guomindang, Mao Yibo pointed out that the so-called revolu-

46 "Fangwen Fan Tianjun xianshengdi jilu" (Record of a Visit with Mr. Fan Tianjun), Ge et al., Wuzhengfu zhuyi sixiang, II, pp. 1039-1048, p. 1043.

${ }^{47}$ Feigan (Ba Jin), "Aiguo zhuyi yu Zhongguoren dao xingfudi lu" (Patriotism and the Chinese Path to Happiness), Jingqun (Warning to the Masses), 1 (1 September 1921), in Ge et al., Wuzhengfu zhuyi sixiang, II, pp. 541-543; (Wei) Huilin, "Shehui geming yu guomin geming"' (Social Revolution and National Revolution), Minzhong, 2.1 (January 1927), pp. 11-21; Tianxin (Shen Zhongjiu), "Gao guojia zhuyizhe" (To Nationalists), Minzhong, 2.2 (February 1927), pp. 100-105.

48 "Zhen Tian yu Faguo wuzhengfu zhuyizhe Gelafudi tongxin" (Zhen Tian [Bi Xiushao's] Correspondence with the French Anarchist Grave), Minzhong, 2.4-5 (May 1927), in Ge et al., Wuzhengfu zhuyi sixiang, II, pp. 729-734. 
tionary Guomindang spent much of its time suppressing real revolutionaries. ${ }^{49}$

Anarchist attitudes toward their competitors on the revolutionary scene were summarized in 1926 in a "Manifesto of the Human Anarchist Alliance" (Hunanqu wuzhengfu zhuyizhe tongmeng xuanyan):

We must break down the errors of other doctrines so that the masses may be led on to the correct path. The evil doctrines of the contemporary world such as imperialism, militarism, capitalism need not be broken down by us; the masses already oppose them. As for the others such Marxism (i.e., Bolshevism and Leninism), integral nationalism (guojia zhuyi), Three Peoples Principles, etc., they have on the surface some truth to them, and there are those among the masses who blindly pursue them. A little examination will show, however, that they are no more than modified revanchism (baofu zhuyi), commandism (shouling zhuyi) and aggressionism (qinlue zhuyi). These doctrines not only cannot resolve humankind's problems, they are on the contrary themselves obstacles to revolution in the path of human progress. ${ }^{50}$

\section{Revolution and organization}

Anarchists continued to phrase their own revolutionary goals in broad humanitarian terms. The Declaration of the Anarchist Federation in 1923 described the goals of revolution to be the elimination of all that was contrary to reason, and the creation of a society of "mutual labor, mutual aid and mutual love" (hulao, huzhu, huai). ${ }^{51}$ The Equality Society (Junshe) in Sichuan sought to bring about "a world organized around love, not killing; a world of mutual aid, not competition". ${ }^{52}$ In 1927, the anarchist/ Guomindang periodical Revolution Weekly (Geming zhoubao) depicted the goals of anarchism as the elimination of all that was old, irrational and harmful and, therefore, unsuited to existence, and the creation of a social organization that was new, rational and beneficial to human existence.$^{53}$ All anarchists agreed that the goal of an authentic revolution was to transform social consciousness, and life at its quotidian level, in order to create receptivity to such a conception of society; their own role was to "incite" the masses to action to achieve such a consciousness. Wu Zhihui estimated

${ }^{49}$ Yibo (Mao Yibo), "Ping Chen Duxiu xianshengdi jiangyan lu" (Critique of Mr. Chen Duxiu's Collection of Speeches), Xuedeng, 20 (November 1924).

${ }^{\text {so }}$ Hudson Collection (The Hoover Institute), Package 6, part 2.

51 "Guangzhou zhenshe xuanyan" (The Declaration of Guangzhou Reality Society), Chunlei, 1 (10 October 1923), pp. 1-5, p. 4.

52 "Junshe xuanyan" (Declaration of Equality Society), Banyue, 21 (1 January 1921), in Ge et al., Wuzhengfu zhuyi sixiang, II, pp. 534-537, p. 535.

${ }_{53}$ Bibo (Bi Xiushao), "Women shishei?" (Who Are We?), Geming zhoubao, 16-18 (1927). See 16, pp. 161-175, p. 172. 
at one point that the anarchist revolution would take about "three-thousand years" to achieve (though he added a few years later that if every anarchist was a Shifu, it might take only "five-hundred years"!). ${ }^{54}$ It would also take many, many revolutions to achieve this goal.

Unlike in earlier years, however, anarchists in the twenties could no longer afford to be satisfied by vague statements of revolution. The Communist challenge was to compel anarchists to pay closer attention to concrete issues of revolution. While they were opposed to the Communist strategy of revolution, anarchists had to evolve a strategy of their own to prove their viability as an alternative to the Communists. This was the most important development in Chinese anarchism in the twenties. It was evident in the increasing attention devoted to three questions with which the Communists presented them: organization, revolutionary strategy, and the defense of revolution (an alternative, in other words, to the "dictatorship of the proletariat").

The need to organize, and to find a suitable means of organization, were major anarchist preoccupations. Anarchists insisted that they were not opposed to organization (as the Communists charged), but only to the kind of organization that was inconsistent with the revolutionary society they sought to create; in other words political organization that took as its aim not social revolution but the conquest of political power, that was hierarchical and coercive in its internal functioning. ${ }^{55}$ Qin Baopu charged with "laziness" anarchists who believed that anarchism should not be organized, or that anarchist organization had no room for discipline, rules and regulations. Organization was a necessity of revolution, he asserted; what distinguished anarchist organization from others was that it must be based on "the will of the masses" (qunzhong yizhi). As with other anarchists, he believed that anarchist organization must move from the bottom up rather than the top down. He proposed as the initial task of organization the founding of "small organizations" (xiao zuzhi) in localities, productive units and schools. These organizations would associate with others in their proximity in "local congresses" (quhui). Except over fundamental issues that required congress decision, the small organizations would be independent in carrying out day-to-day affairs, represented by their secretaries. In this manner, he believed, whole counties and provinces could be organized for action. While other anarchists at the time called for a national congress of anarchists, Qin believed that such a congress would be premature until after localities had been organized. With the country thus orga-

${ }^{54}$ Zhihui (Wu Zhihui), "Jinian Shifu xiansheng” (Remembering Mr. Shifu), Minzhong,

2.3 (March 1927), pp. 161-163, p. 162.

${ }^{55}$ Sanmu (Li Shaoling), "Wuzhengfu zhuyi yanjiu" (Examination of Anarchism), Chunlei, 2 (10 December 1923), pp. 3-4. 
nized, once revolution broke out at the centers of political power, it would spread rapidly. What was most important for the time being was to organize the masses without the use of coercion, which alienated them, as the Bolshevik example showed, and to neutralize others who were potentially opposed to revolution. The revolution he envisaged was a violent revolution, since he believed that power holders were unlikely to relinquish their power voluntarily. ${ }^{56}$

While Qin's proposals represented mainstream anarchist thinking on the question of organization, others were willing to go still further. People's Vanguard magazine, which was more radical than most in its advocacy of class struggle and its opposition to the Guomindang, published an article by Mao Yibo that sounded much like the Bolshevik strategy that the anarchists opposed. While revolution was class struggle, and must ultimately depend for its success on the consciousness of the masses, all revolutions historically had been the work of the few whose consciousness was in advance of the masses they represented; they, therefore, must play a strategic part in arousing the consciousness of others and in leading them in revolution. ${ }^{57}$

Under contemporary circumstances organization from the bottom up was possibly a hopeless dream (as the Communists believed) without a larger organizational umbrella to coordinate and to protect it; but the majority of anarchists refused to entertain any such project. In 1927, Shen Zhongjiu was still pleading with fellow anarchists to overcome their qualms about participating in a national congress. ${ }^{58}$ As we have seen above, anarchist efforts to federate local anarchist organizations were in the end fruitless because they shied away from any suggestion of centralization in the movement.

Be that as it may, anarchist suspicion of centralization accounts also for the direction anarchist revolutionary activity would take. In their discussions of revolutionary strategy, anarchists took as their immediate goal the overthrow of the state and capitalism. In his "How to Resolve the Problems of Present-day Chinese Politics", Ou Shengbai, who was held in high esteem by fellow anarchists for his attention to concrete revolutionary

${ }^{56}$ Baopu, "Wuzhengfudang geming fanglue" (Strategy of Anarchist Revolution), in Ziyou congshu, part 3 ("gemingzhi lu" (the Path of Revolution)), pp. 359-360.

57 (Mao) Yibo, "Geming zhongzhi zhishi jieji yu wuchan jieji" (Intellectual and Proletarian Classes in the Revolution), Minfeng (People's Vanguard), 2.1 (13 February 1927), in Ge et al., Wuzhengfu zhuyi sixiang, II, pp. 795-797. Mao, with the Sichuan anarchists Lu Jianbo, his spouse Deng Tianyu, and Fan Tianjun from Guangzhou was among the leaders of the Young Anarchist Federation which represented the anarchist Left in the late twenties.

\$8 Xintian (Shen Zhongjiu), "Duiyu kai dahuidi yijian" (Views on a National Congress), Ziyou ren (Free People), 3 (May 1924), in Ge et al., Wuzhengfu zhuyi sixiang, II, pp. 758-761. 
problems, discussed the sad state of Chinese politics over the preceding ten years, and went on to outline a program of action:

On the basis of these experiences, we deeply feel that the causes of popular misery are: 1 . Because of the present political system power is concentrated in a few hands with the result that the majority of the people do not have the opportunity for free participation, 2. Because of the capitalist system all means of production are concentrated in the hands of the capitalists with the result that the benefits that ought to accrue to laborers are usurped by capitalists.

Therefore, if we wish to pursue the happiness of the people, we must seek to reform both the political and the economic system; the principle of reform is nothing but advancing from a situation of extreme absence of freedom to relative freedom. The important points are: 1 . abolish the system of warlord and bureaucratic control nationally and provincially to institute burghers' self-government in cities, and to establish a national association of selfgoverning cities and villages, 2 . abolish capitalism, return all means of production to public ownership by the producers, so that only the producers have the right to use and enjoy them.

From the perspective of political theory, the narrower the scope of state power, the freer are the people; therefore, before the abolition of the state, those who pursue the happiness of the people should diminish the power of the state to a minimum. Economically, the products of labor should belong to the self or those with whom the self wishes to share; so that each exerts him/herself to the utmost in the increase of production. Therefore, "burgher self-government" and the "socialization of production" are the path to freedom and equality. ${ }^{59}$

While most anarchists agreed that economic and political powerholders constituted the major targets of revolution, there was some disagreement over who was to be included among the forces that would carry out the revolution. Ou Shengbai, Qin Baopu and syndicalists such as Shen Zhongjiu and $\mathrm{Lu}$ Jianbo conceived of revolution in class terms, and looked to urban and rural laborers as the main force of revolution. Intellectuals were more problematic; while Baopu restricted revolution to the "masses", and included the "petit-bourgeoisie" among the forces that had to be "neutralized", Mao Yibo as we have seen above privileged them with a vanguard role for their revolutionary consciousness. Anarchists also differed over their emphases on urban and rural laborers, although they did not necessarily view rural and urban revolution as being mutually exclusive. Some, however, did believe that because China was an agrarian society, the proletariat did not have much of a role to play in the revolution; one such

${ }^{59}$ Ou Shengbai, "Zhongguo muqiandi zhengzhi wenti ruhe jiejue", Minzhong, 1.5 (10 July 1923), in Ge et al., Wuzhengfu zhuyi sixiang, II, pp. 634-636, pp. 635-636. 
anarchist pointed to peasants, women and soldiers as the groups upon which anarchists should concentrate their attention..$^{60}$

Revolutionary institutions of anarchism; labor syndicates/rural communes Anarchists had long argued that a meaningful social revolution must in the very process of revolution create the institutions upon which future social organization would be based. Two institutions were foremost in anarchist discussions of revolutionary strategy at this time that also provided the main objects of anarchist revolutionary activity: syndicates for organizing urban laborers and communes for the organization of villages. Some also believed, interestingly, that the "people's militia" (mintuan) in the villages, an age old institution in China, could be utilized fruitfully both in carrying out and in defending the revolution.

Chinese anarchists, starting with Shifu's Federation in Shanghai in 1915, had stressed syndicates (gongtuan, to be distinguished from "labor unions", gonghui) as organizations that would serve not only as agents of revolution but as the cores for laborers of future social organization. The "Declaration of the Shanghai Branch of Anarcho-communists" stated in 1924:

The society of the future not only will stamp out bureaucrats, capitalist and their appendages, but also put an end to distinctions between intellectuals, workers, peasants and merchants. Everyone will labor for society, and become laborers who will work both with their minds and their hands. In order to meet the needs of production for necessities or luxuries, to satisfy general or particular needs, these laborers will organize themselves in a variety of groups (tuanti). These groups will federate freely with other groups, and replace present-day political organization. In order for these freely organized groups to fulfill their promise, it is absolutely necessary to overthrow the present system. But these groups cannot be established overnight; if a basis for them is not instituted presently, when the revolution comes about and the old system is overthrown without a new one to replace it, all will be chaos. It is best for the workers of the whole world or the whole country to unite (tuanjie qilai), to declare war upon capitalist and the government through such methods as the general strike (zongtongmeng bagong), on the one hand, and, on the other hand, to establish a foundation for future society. It is because of this that many anarchists also advocate syndicalism. ${ }^{11}$

Shanghai was in the twenties the center of anarchist syndicalist activity. Anarchists had been the first to organize modern labor unions in China, first in Guangzhou and then in central China, in Hunan. Their influence in

60 “" 'Jieji zhanzheng' he 'pingmin zhuanzheng'", p. 590.

61 "Wuzhengfu gongchandang Shanghaibu xuanyan", Ziyou ren, 3 (May 1924), in Ge et al., Wuzhengfu zhuyi sixiang, II, pp. 751-757, p. 753. 
labor unions declined (though it did not disappear) in Guangzhou after the alliance with the Guomindang allowed the Communists to make inroads into labor organization in the South. In central China, the bloody suppressions of labor organization in 1922-1923, and once again the increase in Communist influence, drove Hunanese anarchists to Shanghai, where they quickly assumed an important role in the burgeoning syndicalist activity. The Federation of Shanghai Syndicates organized in 1924 held sway over forty to fifty labor organizations and roughly fifty-thousand workers. ${ }^{62}$ The Federation (which the Communist labor organizer and historian Deng Zhongxia would describe as an organization of "vagabond unions") was not an anarchist organization; Guomindang labor leaders played an important part in it, and some of its member unions were less interested in the promotion of labor interests than in reconciling labor and capital - which was not necessarily inconsistent with the anarchist wish to bring about a revolution that transcended class interest. Anarchists possibly played an important part in day-to-day activity, however, and the ideological slogan of the Federation, "Let us ask for bread only, and leave politics alone", reflected the orientation of the anarchists who sought to spread among Federation members the anarchist message: "resolve economic problems, oppose all politics, engage in direct action, do not rely upon any party". ${ }^{63}$ So did the choice of "syndicate" over "labor union" that the Federation adopted in describing itself.

Anarchists had also been the first among Chinese social revolutionaries to raise the question of a rural revolution. Shifu's followers had made the first attempt to establish an agrarian commune in the mid-1910s. Under anarchist inspiration, the idea of "going to the people" had gained currency in Chinese radicalism during the May Fourth Movement. The "new village movement" that flourished in 1919-1920 did not necessarily refer to the establishment of rural communes but rather to communes that made agricultural work part of their daily activity; it nevertheless helped spread a rural orientation among urban radicals. In the aftermath of the May Fourth Movement anarchists took the lead in carrying revolution in the countryside. It is also possible that Communists who distinguished themselves in agrarian activity in the early 1920s, such as Peng Pai in Guangdong, turned to agrarian activity initially under anarchist inspiration.

Anarchists in the twenties believed that agrarian activity should go beyond the establishment of "new villages", which were "escapist" in

${ }^{62}$ Kosugi Shuji, "Shanghai koodan rengookai to Shanghai no roodoo undoo" (The Federation of Shanghai Syndicates and the Shanghai Labor Movement), Rekishigaku Kenkyu (Historical Studies), 392 (January 1973), pp. 14-73, pp. 18-19.

${ }^{63}$ For the Federation, see Jean Chesneaux, The Chinese Labor Movement, 1919-1927 (Stanford, 1968), pp. 223-227, 252-259, as well as Kosugi. For the anarchist involvement, see below. 
nature, and seek to revolutionize the existing village. ${ }^{64}$ At least some among the anarchists took this to heart. Judging by the literature (which is sparse and sporadic), anarchists associated with Jing Meijiu in the North may have played a significant part in this regard. Jing, the editor of National Customs Daily, had been introduced to anarchism in 1907-1908 while a student in Japan, and his anarchism carried the imprint of the Tokyo anarchists who promoted an anti-modernist anarchism that drew upon native ideals and Tolstoyan ideas, and stressed a rural life in which mental and manual labor, agriculture and industry would be combined. Jing himself had engaged in attempts to promote cooperative enterprises in his native Shanxi even before the 1911 revolution. ${ }^{65}$ The Sea of Learning, supplement to his National Customs Daily often published articles on rural revolution. In June 1923, a draft program for an "Alliance for an Agrarian Movement" (Nongcun yundong tongmeng) appeared in the paper that stated as its goal "the use by tillers of their own power to acquire for themselves profit and happiness". The Alliance program was to advance the organization of tillers, establish a federation of such organizations, help the tillers acquire land and promote self-government. ${ }^{66}$

The Sea of Learning was not alone in promoting an agrarian movement. Anarchist periodicals were rife with reports on attempts to establish communes or promote rural revolution across the face of China. An anarchist objection to Marxism was that Marxism, with its preoccupation with the proletariat, had a blind spot toward the peasantry and ignored 80 percent of the world's population. Communism was unsuitable in China, some anarchists believed, because China was still a largely agrarian society; some went so far as to criticize the Communists for their fetishism of development, which led them to overlook the virtues of agrarian society. They argued that anarchism was much more suitable in organizing a society where, owing to thousands of years of agrarian existence over which the state had little power, the population had evolved habits of self-government conducive to anarchism. Others added that revolution was easier in the village both because of these habits, and also for tactical reasons; unlike the proletariat, which had to compel the bourgeoisie to turn over their property to workers, all peasants needed to do by way of struggle was to keep what they already had. ${ }^{67}$ An anarchist society in Shaanxi in the North perceived

64 Daneng, 'Xiangcun yundong tan" (On the Agrarian Movement), Chunlei, 2 (10 December 1923), p. 2.

"s Jing, "Zuian", pp. 145, 147.

${ }^{66}$ Nongcun yundong tongmeng guiyue caoan", Xuehui, 236 (29 June 1923), in Ge et al. , Wuzhengfu zhuyi sixiang, II, pp. 673-674.

67 Huang, "Letter", p. 118; Jianhun, "Bagong yu jugeng" (Strikes and Seizing Land), Minzhong, 1.5 (10 July 1923), in Ge et al., Wuzhengfu zhuyi sixiang, II, pp. 632-633. 
in the self-governing village a model for anarchist reorganization of the world. ${ }^{68}$

Some anarchists argued that the village militia offered a particularly effective means for revolutionary reorganization of the village. As selfdefense organizations for the rural population, they believed, the militia had played a revolutionary role throughout Chinese history; although most of the time the government had managed to bring them under control and turn them to counterrevolutionary purposes. The task was to render them independent, and bring them around to opposition to the state. With the right training, not only the militia but even bandits could be brought around to the anarchist cause. Such training should include military training for both men and women, and education through films and public performances (plays and operas) as well as written materials on revolutionaries and revolution. Once this was accomplished, it was necessary to make sure that they were well provisioned and inclined to union with other militia. The militia, thus re-formed, would not only plan an important part in bringing about the revolution, but also in defending it against counterrevolution. In the words of Li Shaoling:

The last few years, I have constantly been thinking of a short-cut to revolution without much success. Education is the most reliable method but also very slow. The new village is very difficult under conditions of warlord rule; scattered uprisings sacrifice many lives without significant consequence. After much thought, I have decided that militia offer a relatively reliable and quick method. Just speaking of instances with which I am familiar, the cases of Hunan and Guangdong, in these two provinces the militia are strong; they often chase away government and warlord forces, or render them ineffective. While there are those in them who are no good, their revolutionary spirit in opposing the government is inextinguishable [ . . . I I raise this issue with the hope that comrades will examine it with care. ${ }^{69}$

Some comrades apparently did. In the late twenties, Fan Tianjun participated in an anarchist led militia in Fujian that sought to establish a "base area" (after the Communist model). For a brief period its success was such that it even attracted the attention of Japanese anarchists who thought that Fujian might become the base for an East Asian anarchist revolution! $!^{70}$

\section{Social and cultural revolution in anarchist activity}

Whether urban or rural, anarchist revolutionary activity followed a common pattern which reveals that in spite of a desire to meet the Communist

68 "Shaanbei nongshe yundongdi xuanyan" (Declaration of the Village Commune Movement in Northern Shaanxi), Chunlei, 1 (10 October 1923), pp. 141-143, p. 142.

${ }^{69}$ Sanmu (Li Shaoling), "Mintuan geming" (Revolution of People's Militia), Minzhong, 1.12 (July 1925), in Ge et al., Wuzhengfu zhuyi sixiang, II, pp. 704-710, pp. 709-710.

70 "Fangwen Fan Tianjun", pp. 1040-1041, p. 1045. 
challenge, it was an anarchist conception of revolution that shaped anarchists' revolutionary strategy. The point of departure and the end of this activity was the transformation of workers' and peasants' social consciousness, to stimulate among them a "self-awareness' (zijue) that would enable them to take charge of their own struggles against power. While anarchists did come to occupy leading roles in the organizations they established, they could claim with some fairness that, unlike their Communist counterparts, they did not seek to achieve the sway upon the masses of a political organization but rather to help them organize to pursue their own interests (which is credible if only because this was the flaw in anarchist revolutionary strategy). The cornerstone of anarchist revolutionary activity was education, not education in the ordinary sense which they rejected, but an education for revolution that made no distinction between formal education and propaganda, that took as its primary goal the transformation of quotidian life and consciousness. The tactics were simple: establish contact with laborers (proletarian or peasant); through the help of these contacts organize workers' clubs and part-time schools in which worker participation would be encouraged; gradually move on to the organization of a union as the confidence of laborers was secured. If this does not sound very different from Communist tactics, it is because they were not very different, except in goals. Anarchists, however, had been using these tactics for nearly three years when Communists adopted them in their first overtures to labor in $1920 .^{71}$

We have glimpses of these activities from two reports published in the Anarchist Federation journal, Spring Thunder, one on urban the other on rural activities. The former was a report on anarchist activities in Shanghai published in early 1924 . According to the report, anarchists of the Free People Society (led by Shen Zhongjiu, who cooperated closely with Hunanese anarchists in Shanghai) had been active in the establishment of the Federation of Shanghai Syndicates, as well as a complementary organization, Union of Young Laborers (Laogong gingnianhui). They published their own periodical, Free People, as well as two labor journals associated with these organizations, Labor Ten-daily (Laodong xunkan) and Young Laborers Ten-daily (Laogong qingnian xunkan). They conducted educational activity in factories with unions associated with the Federation, spreading the message "resolve economic problems, oppose all politics, engage in direct action, do not rely upon any political party". In conjunction with these educational activities, they were in the process at the time of planning for a labor university (laodong daxue). ${ }^{72}$

${ }^{71}$ Liu Shixin, "Guanyu wuzhengfu zhuyi", pp. 937 gives a brief account of these methods.

72 "Tongzhi xiaoxi", Jingzhe, 1 (1924). 
Anarchists would not achieve their dream of establishing a labor university until 1927 when, under the auspices of Guomindang anarchists, they were able to establish the National Labor University (Guoli laodong daxue) which for a brief period promised to fulfill their goal of training a new kind of labor leader, drawn from among the ranks of laborers, who would be at once a laborer and an intellectual, overcoming a distinction that had long divided society into "classes". The plans for such a university were laid as early as 1924. The statement of intention anarchists drew up at the time is revealing of their approach to labor and, therefore, the ultimate intention underlying their revolutionary activities:

What is laborer education? It is the kind of education to advance the self-awareness of laborers; it is the kind of education that will help laborers advance from the status of slave to that of human being (ren); it is the kind of education that will help laborers' abilities and show them how to pursue a labor movement. Simply put, laborers' education is the education of laborers to become human beings; it is an education in revolution because for laborers revolution and becoming human beings are inseparable. If they want to become human beings, to be independent and free, to sustain life, to satisfy their spiritual needs and not be exploited, controlled or oppressed, is there any way other than revolution? ${ }^{73}$

The report on agrarian activity (published December 1923) concerned an unnamed village in Guangdong where anarchists had been active for the previous two years. According to the author, Daneng (a pen name), the village school had played an axial role in these activities. Recalling the experiences in establishing a peasants' association, he related that they had started off with a night school where, in addition to teaching the villagers basic reading and arithmetic, they had told their pupils stories of world revolution and revolutionaries, which gradually made the villagers feel that revolution might bring about an improvement in their lives. On May Day, they distributed pamphlets among the villagers, held a lantern parade, and concluded the festivities with a "revolutionary opera". Soon after, the villagers came to them with a request for organization. ${ }^{74}$ Similarly, anarchists in northern Shaanxi combined general and revolutionary education to gradually mobilize villagers; in their case a general education to stimulate self-awareness combined with technical education to improve productive methods. ${ }^{75}$

Education remained for the anarchists the most "reliable" method of revolution. Nevertheless, the experience of failure in the face of oppres-

${ }^{73}$ Linyi, "Sinian qian Zhongguodi Laodong daxue" (The Chinese Labor University of FourYears Ago), Geming zhoubao, 29-30 (December 1927). See no. 29, p. 286.

${ }^{74}$ Daneng, "Xiangcun yundong tan", pp. 4-5.

75 "Shaanbei nongshe yundongdi xuanyan", p. 142. 
sion, and the challenge of the Communist advocacy of proletarian dictatorship, taught at least some of the anarchists that the creation of revolutionary institutions was not sufficient to make revolution, that they must also find ways to defend revolution against its enemies. This was a major reason in $\mathrm{Li}$ Shaoling's consideration of people's militia as an instrument of revolution. A similar idea was proposed in 1924 by the prominent Guangzhou anarchist Liang Bingxian, this time for urban areas. Liang argued that inasmuch as education was crucial to revolution, revolution entailed questions of power and would certainly end up in failure if it could not defend itself. $\mathrm{He}$, therefore, proposed the establishment of "revolutionary corps" (geming tuanti) to supplement syndicates. Ultimately it was the syndicates that would provide the basis for social and economic reorganization, but in the period of transition the "revolutionary corps" would play a crucial role in overthrowing the power of the state and the bourgeoisie and defending the revolution against them. Liang's proposal emphasized urban areas but was not restricted to them. Revolution, he believed, could not be successful unless it encompassed rural areas. ${ }^{76}$

These schemes represented an anarchist answer to a transitional period in the revolution that for the Communists was encapsulated in "dictatorship of the proletariat". Anarchists had earlier believed that once the revolution broke out, the "natural" inclination to anarchism in all human beings would quickly usher in anarchist society. That the revolution would involve power, require a period of armed preparation, warfare and defense before achieving its social goals revealed a new soberness toward questions of revolution that anarchists owed to the Communist challenge. ${ }^{77}$ They repudiated the dictatorship of the proletariat unconditionally, but they could not ignore the very real questions that it raised. Unlike their Communist opponents who justified dictatorship by necessity but also learned quickly to celebrate it in endless affirmations of the indispensable vanguard role of the Communist Party, however, anarchists remained reluctant to break with the commitment to popular initiative that informed their revolutionary vision. Their methods were at best reluctant compromises with the realities of power, but not enough of a compromise to bring to them any significant gains in the contest for revolutionary leadership.

\section{In retrospect}

"Heaven helps those who help themselves", an anarchist wrote in People's Tocsin in 1927, and went on to complain that for lack of an organization,

${ }^{76}$ (Liang) Bingxian, “Gemingdi gongtuan” (Revolutionary Syndicates), Minzhong, 1.7 (10 March 1924), in Ge et al., Wuzhengfu zhuyi sixiang, II, pp. 701-704.

$n$ See the stages of revolution Li Shaoling outlines in "Mintuan geming", pp. 707-710. 
anarchists were busy cultivating others' gardens instead of their own. ${ }^{78}$ The reference was to anarchists' cooperation with the Guomindang. Such cooperation was not new, but when the Guomindang broke with the Communists in 1927, anarchists saw an opportunity to pursue their cause within the Guomindang. While some anarchists remained adamantly opposed to such cooperation (among them Ou Shengbai and the Sichuan anarchists Ba Jin and Lu Jianbo), others formerly opposed to it (such as Shen Zhongjiu) could not resist the temptation. The most visible manifestation of the cooperation was the Labor University, and the journal Revolution Weekly associated with it, in which Shen Zhongjiu, Bi Xiushao and Hunanese anarchists, as well as foreign anarchists such as Jacques Reclus (grandnephew of Elisee Reclus who had first inspired Li Shizeng to anarchism in Paris) played important parts, under the sponsorship of the Guomindang anarchists Li Shizeng and Wu Zhihui. ${ }^{79}$ Other important anarchists, including Shifu's brothers Liu Shixin, remained active in the labor movement in Guangzhou under Guomindang auspices. ${ }^{80}$ Ironically, the anarchist rejection of politics seems to have made for some willingness to work with other political groups so long as they were not compelled to abandon anarchism for another ideology.

For some the cooperation continued to the period of the war with Japan after 1937. Other anarchists would end up joining the Communist Party. Through it all, the anarchists did make an effort to retain their identity as anarchists. The anarchists in Labor University turned to the criticism of Jiang Jieshi (Chiang Kai-shek) and Wu Zhihui when the Guomindang suppressed in 1928 the mass movements that they had hoped to lead. Revolution Weekly was shut down in 1929, and though the Labor University stayed open until 1932, it had already by 1928 lost the revolutionary mission it had initially assumed in anarchist eyes. Anarchist plans for revolution may not have disappeared but they had evaporated.

These plans appear at first sight not as products of a serious pursuit of revolution but as the fanciful game-plans of young radicals playing at revolution (most of the anarchists were indeed quite young). The evidence presented above will hopefully clear away such an impression. Idealistic the anarchists may have been in their efforts to remain true to their vision, but they were dead serious as revolutionaries. Their revolutionary activities overlapped with those of the Communists; in their approaches to strategies of both urban and rural revolution, they were the first to utilize methods that would also become the methods of Communists, and carry the latter to

78 Zheng Tie (Bi Xiushao), "Zhong women zijidi yuandi" (Cultivating Our Own Garden), Minzhong, 2.2 (February 1927), pp. 81-83.

${ }^{79} \mathrm{Bi}$, "Wo xinyang wuzhengfu zhuyi", pp. 1030-1031.

${ }^{80}$ Huang Yibo, "Wuzhengfu zhuyizhe zai Guangzhou", pp. 5-14. 
success when the political environment was hospitable to their practise. They were also willing to learn from the Communists, and to risk some measure of compromise to meet the challenge with which the Bolshevik strategy of revolution presented them.

What they were unwilling to do was to postpone their revolutionary aspirations indefinitely in order to achieve immediate success. This is not to suggest that anarchists were the only revolutionary purists on the scene, or that they did not make serious errors. Their effort to discredit Marxism rather than to listen carefully to what Marxist theory had to say about society blinded them to concrete problems of revolution as much as the Communist disdain for anarchism blinded Communists to what they had to say about the relationship between revolutionary vision and practise. The vagueness of their social analysis deprived them (as the Communists charged and they were willing to concede in the end) of a viable method of revolution.

We ought to remember, nevertheless, that the Communists were themselves quite vague on social analysis on occasion, and they themselves believed in the possibility of alliances that transcended classes. What they had that the anarchists did not have was a political organization that ultimately stood as a point of reference for all revolutionary activity, coordinated and gave it direction, and was able, once it had realized the necessity, to protect such activity with power. Theory and vision, once they were embodied in the Communist Party, acquired a concreteness and purpose, which gave direction in Communist hands to the same methods of revolution that the anarchists had pursued. Anarchist revolutionary activities do indeed resemble purposeless revolutionary play in the absence of a comparable organization. Nevertheless, what endows them with revolutionary seriousness was their realization that the organizational capture of revolution would irretrievably divert revolution from the intention that gave it its meaning.

The opposition to organizational centralization per se does not reveal the full distinctiveness of the anarchist argument, or its thoroughgoing radicalism. There is another, deeper aspect to the problem that brings into relief anarchist differences not just with Bolshevism but with Marxism, what we might call the "deep structure" of anarchism that may in the long run be more significant than any specific contributions anarchists may have made to revolutionary strategy in China; what I described above as the denial of a center to revolution, which was an implicit determinant of anarchist revolutionary activity, not only in their rejection of an organizational center to revolution but also in their suspicion of any conceptualization of society that presupposed a center to society and history, be it the proletariat or even the very idea of class. Indeed, it may be suggested that the anarchist idea of freedom and democracy was inextricably linked with a desire to 
abolish a prevalent tendency to view society in terms of a "center". The editorial in the first issue of Spring Thunder, the journal of the Anarchist Federation, argued just such a case. The author, Wang Siweng (who was also the editor), based his case for anarchism on the assumption of the "naturalness" of division of labor and cooperation in society (fengong hezuodi shehui shenghuo). What made this "natural" was that it was a reflection in society of the functioning of the cosmos, as modern science understood it. Since the sixteenth century when people had still believed that human beings were the center of the universe, science had discovered that there was no power that was almighty and, therefore, the center of the universe. From the solar system to the minutest particles of life, from the solar system to all the solar systems in the universe, there was no single unit that controlled the universe or even the immediate space around it. Everything depended rather on relationships, which shaped the large as well as the small (the sun as much as the planets), made them equally independent and equally dependent on one another. Human organization must be egalitarian, because the organization of the cosmos was egalitarian ( $y u$ zhoudi zuzhi, gewei pingheng). Likewise, human organization must strive to achieve freedom for all regardless of place, gender, class or race because there was no such thing in the cosmos as one entity ruling others. ${ }^{81}$

Wang did not acknowledge any debt to others in his essay, but textual similarities suggest that his discussion was mostly derivative of Kropotkin's "Anarchism: Its Philosophy and Ideal", where Kropotkin had initially made the case for "decentering" society and history so that humankind could reconstitute itself on the basis of freedom and equality, the preconditions for a social existence of mutual aid. Speaking of recent developments in astronomy, he wrote, cogently: "Thus the center, the origin of force, formerly transferred from the earth to the sun, now turns out to be scattered and disseminated". His survey of the modern sciences confirmed this fundamental finding of astronomy. ${ }^{82}$

It may be that in a world without center, politics, including revolutionary politics, has no point of departure. In this, however, anarchists saw not the threat of chaos but the possibility of a new beginning for humanity, this time on the basis of free and equal association. In this particular sense anarchists were also correct, I might add, in arguing that Marxism shared much in common with the philosophies it rejected because the pursuit of a center to replace the centers of old society would seem to be characteristic of all

${ }^{81} \mathrm{Si}$ (Wang Siweng), "Hewei er xinyang wuzhengfu gongchan zhuyi" (What are Anarcho-communist Beliefs), Chunlei, 1 (10 October 1923), pp. 5-19. Needless to say those arguments also distinguished the anarchists from anti-political social conservatives, on the one hand, and individual-oriented libertarians, on the other hand.

${ }^{82}$ Peter Kropotkin, Revolutionary Pamphlets, Roger N. Baldwin (ed.) (New York, 1968), pp. 114-115, p. 117. 
varieties of Marxism, and in Marx's own location of a center to history in class struggle which, as the anarchists pointed out, had led to a Marxist neglect of other struggles in history - and other possibilities of liberation. In 1921, participants in the May Day parade in Guangzhou arrived at a crossroads where they were greeted by two portraits hanging on opposite sides of the street, one of Marx, the other of Kropotkin. ${ }^{83}$ This may have been the last occasion of such an encounter. In ensuing years, Marx and Kropotkin inexorably moved farther and farther apart in the thinking of Chinese radicals. Anarchists were to lose by their rejection of Marx. Communists would win the revolution, but the repudiation of anarchism once the Communist Party had been established would also exact a price upon their revolutionary vision, if in less visible ways.

${ }^{83}$ Zheng, “Wuzhengfu zhuyi", p. 199. 